\title{
NOTE
}

\section{Effectiveness of a vaccine against red sea bream iridoviral disease in a field trial test}

\author{
Kazuhiro Nakajima ${ }^{1, *}$, Yukio Maeno ${ }^{1}$, Atsushi Honda ${ }^{2}$, Kenichi Yokoyama ${ }^{3}$, Tetsurou Tooriyama ${ }^{3}$, \\ Sadao Manabe ${ }^{3}$ \\ 'National Research Institute of Aquaculture, Fisheries Agency, Nansei, Mie 516-0193, Japan \\ ${ }^{2}$ Nagasaki Prefectural Institute of Fisheries, Taira, Nagasaki 851-2213, Japan \\ ${ }^{3}$ Research Foundation for Microbial Diseases of Osaka University, Yahata, Kanonji, Kagawa 768-0061, Japan
}

\begin{abstract}
Since 1990, red sea bream iridovirus (RSIV) has caused high mortalities in the summertime in cultured red sea bream Pagrus major in southwest Japan. To establish control measures for red sea bream iridoviral disease (RSIVD), the effectiveness of a formalin-killed viral vaccine was evaluated in a field trial. Two groups each consisting of 1000 juvenile red sea bream were either intraperitoneally inoculated with vaccine (vaccinated group) or were not vaccinated (nonvaccinated group). After vaccination, the fish were held for $1 \mathrm{wk}$, then transferred to a marine net pen and observed for $12 \mathrm{wk}$. The cumulative mortalities caused by RSIVD in the vaccinated group or control group were 19.2 and $68.5 \%$, respectively. Additionally, the presence of virus antigen in the spleen was investigated and body weight was measured 6 and 12 wk post vaccination. In the vaccinated group, viral antigen was not detected. The increase in body weight of vaccinated fish was significantly $(p<0.05)$ greater than that of control fish. These results suggest that the vaccine against RSIVD was effective in 1 field trial.
\end{abstract}

KEY WORDS: Red sea bream iridoviral disease - Iridovirus . Viral disease $\cdot$ Marine fish - Natural infection Vaccination

Red sea bream iridovirus (RSIV) causes an acute and highly contagious disease, tentatively designated red sea bream iridoviral disease (RSIVD). Since 1990, outbreaks of RSIVD have resulted in high mortalities in cultured red sea bream Pagrus major in southwest Japan, primarily in the summertime. The disease has caused mass mortalities among cultured marine fish, which include 18 Perciformes, 1 Pleuronectiformes and 1 Tetradontiformes (Matsuoka et al. 1996). A recent survey showed that 25 species of fish are susceptible

•E-mail: kazuhiro@nria.affrc.go.jp to this virus (authors' unpubl. data). Diseased fish became lethargic and exhibited severe anemia, petechiae of the gills, and enlargement of the spleen (Inouye et al. 1992). The causative virus is a large, icosahedral, cytoplasmic DNA virus measuring 200 to $240 \mathrm{~nm}$ in diameter. The virus isolated from various cultured marine fish is similar but distinct from epizootic haematopoietic necrosis virus (EHNV, Langdon et al. 1986), iridovirus isolated from sheatfish Silurus glanis (SFIV, Ahne et al. 1989) and iridovirus isolated from nursing grouper Epinephelus malabaricus (GIV, Kasornchandra \& Khongpradit 1997). Although cross reactivities were observed between RSIV and other fish iridoviruses by an immunofluorescence (IF) test or immunoprecipitation test using anti-RSIV serum, none of the monoclonal antibodies (MAbs) against RSIV reacted with EHNV-, SFIV- or GIV-infected cells (Nakajima et al. 1998). In addition, the pathogenicity of EHNV, SFIV and GIV to red sea bream has not been demonstrated (Nakajima \& Maeno 1998). Diagnostic methods such as an IF test and polymerase chain reaction amplification were reported (Nakajima \& Sorimachi 1995, Nakajima et al. 1995, Kurita et al. 1998, Oshima et al. 1998). However, control measures for this disease have not been established. Recently, we reported on the effectiveness of a vaccine against RSIVD under laboratory conditions (Nakajima et al. 1997). Herein, we describe the results regarding the effectiveness of the vaccine evaluated in a field trial.

Materials and methods. To evaluate the vaccine, 2000 red sea bream juveniles (mean body weight $6.2 \mathrm{~g}$ ) were divided into 2 groups (vaccinated group and nonvaccinated group). For the vaccinated group, fish were intraperitoneally inoculated with $0.1 \mathrm{ml}$ of vaccine solution made from the supernatant of RSIV-infected 
Grunt fin (GF) cells. For the preparation of a vaccine from the supernatant of RSIV-infected GF cells, the culture medium of RSIV-infected GF cells was centrifuged at $2500 \times \mathrm{g}$ for $10 \mathrm{~min}$ at $4^{\circ} \mathrm{C}$. Formalin $(0.1 \%$ $\mathrm{v} / \mathrm{v})$ was then added to the supernatant, which contained $10^{7.5} \mathrm{TCID}_{50} \mathrm{ml}^{-1}$ of the virus, and the virus was inactivated for $12 \mathrm{~d}$ at $4^{\circ} \mathrm{C}$; then inactivation of the virus was confirmed. The other group, which served as controls, were non-treated. After vaccination, the vaccinated fish were kept in tanks for $1 \mathrm{wk}$ then moved to a seawater net pen $(2.5 \times 2.5 \times 2.5 \mathrm{~m})$. The control fish were kept in tanks for $1 \mathrm{wk}$ and moved to a seawater net pen neighboring the net pen which contained the vaccinated fish. Mortality in these groups was recorded daily for $12 \mathrm{wk}$ post vaccination, and the diagnosis of RSIVD was made on the basis of clinical signs of disease and by means of an IF test with a MAb previously described (Nakajima \& Sorimachi 1995, Nakajima et al. 1995). Fixed imprints of the spleen were covered with $\mathrm{MAb} M 10$ and allowed to incubate at $37^{\circ} \mathrm{C}$ for $30 \mathrm{~min}$ in a humidified chamber. After the slides had been rinsed 3 times for 1 min with phosphate-buffered saline (PBS), the secondary antibody with fluorescein isothiocyanate (FITC)-conjugated goat anti-mouse IgG was applied at $37^{\circ} \mathrm{C}$ for $30 \mathrm{~min}$. The preparates were rinsed again with PBS, mounted in glycerol, and examined with a microscope to identify IF-positive cells. For the diagnosis of RSIVD, all the dead fish were examined on the basis of clinical signs of disease. For the diagnosis of RSIVD using an IF test with a MAb, all fish were examined when the number of fish which had died was less than 10 fish at 1 sampling. When the number of fish which had died exceeded 10 at 1 sampling, 10 fish were examined. Sampling was done once a day. Statistical analysis was carried out using a $\chi^{2}$ test. The relative percentage survival (RPS, Amend, 1981) was also determined by the formula RPS = $[1-1 \%$ loss of immunized fish $/ \%$ loss of controls] $] \times 100$. To detect viral antigen, 10 survivors were randomly sampled in each group. Then, the spleens were removed from the fish and the presence of RSIV-specific antigens was determined by means of an IF test. Mean body weight of 100 fish randomly sampled from each group was also determined 6 and $12 \mathrm{wk}$ post vaccination.
Results and discussion. At 12 d post vaccination, mortalities were first observed in the control groups. Between 40 and 50 d post vaccination, mortalities peaked (Fig. 1B) and the cumulative mortalities caused by RSIV in control non-treated fish were $68.5 \%$ (Fig. 1A). However, deaths among vaccinated fish began later than those among control fish, and the cumulative mortality in vaccinated fish caused by RSIV was $19.2 \%$ (Fig. 1). The dead fish exhibited severe anemia, petechiae of the gill, and enlargement of spleen, which are typical signs of the disease. Viral antigens were detected from the spleens of dead fish. The results showed that the vaccinated groups had a higher relative survival than the control group. RPS of the vaccinated fish was $72 \%$. $\chi^{2}$ analysis showed differences in the mortalities of the
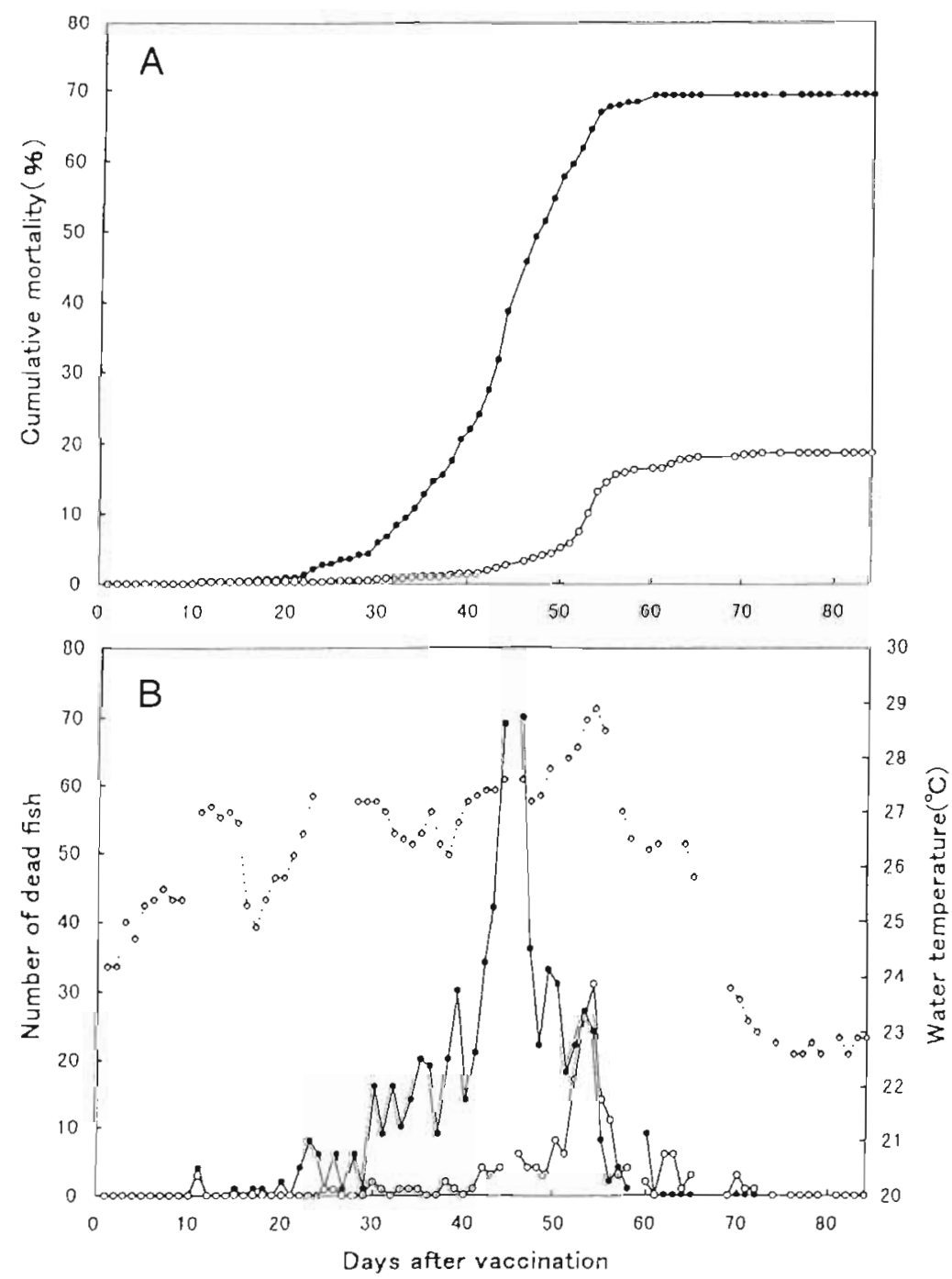

Fig. 1. Pagrus major. Mortality of vaccinated and non-treated fish in a field trial test. Juvenile red sea bream were vaccinated by intraperitoneal injection $(0)$. Control fish $(\bullet)$ received no treatment. Cumulative mortalities are shown in (A) and the number of dead fish from the vaccinated and control groups and ambient water temperature $(0)$ are shown in $(B)$ 
vaccinated and non-vaccinated groups to be significant $(p<0.01)$. This disease frequently occurs when the ambient temperature is more than $25^{\circ} \mathrm{C}$. Thus, the decline in temperature was responsible for the decline in morbidity (Fig. 1B).

The presence of viral antigen in the spleen was also examined. In the vaccinated group, viral antigen was not detected in 10 fish examined at 6 or $12 \mathrm{wk}$ post vaccination. In contrast, in the control group, viral antigen was detected in all the 10 fish examined at $6 \mathrm{wk}$, but was not detected in the 10 fish examined at 12 wk post vaccination. These results showed that the vaccine prevented the appearance of viral antigen in the spleen of immunized fish at 6 wk post vaccination, when mortalities caused by RSIV frequently occurred. The average body weights of vaccinated and control fish were $35.6 \pm 5.12$ and $30.8 \pm 5.12 \mathrm{~g}$ at $6 \mathrm{wk}$ post vaccination and $66.4 \pm 9.14$ and $63.6 \pm 10.3 \mathrm{~g}$ at $12 \mathrm{wk}$ post vaccination, respectively. The difference in the increase in the body weight of fish in the vaccinated and non-vaccinated group is statistically significant $(p<0.05)$.

In addition to the effectiveness of the vaccine in an experimental infection previously reported (Nakajima et al. 1997), this vaccine against RSIVD has proven successful in the prevention of RSIVD in red sea bream in 1 field trial. Therefore, this vaccine will be the control measure for this disease. The development of a killed virus vaccine and of an injection delivery method will be a very important health management tool in the prevention of RSIVD. This disease has occurred not only in red sea bream but also in various other cultured marine fish. The causative viruses isolated from various diseased fish were shown to be similar (Nakajima et al. 1998). So, the effectiveness of the vaccine in cultured marine fish is also promising. In addition to the trial reported here involving red seabream, further trials using cultured marine fish such as yellowtail Seriola quinqueradiata, amberjack Seriola dumerili, striped jack Pseudocaranx dentex are needed.

Editorial responsibility: Jo-Ann Leong,

Corvallis, Oregon, USA

\section{LITERATURE CITED}

Ahne W, Schlotfeldt HJ, Ogawa M (1989) Fish viruses: isolation of an icosahedral cytoplasmic deoxyribovirus from sheatfish (Silurus glanis). J Vet Med 36:333-336

Amend D (1981) Potency testing of fish vaccines. Dev Biol Stand 49:447-454

Inouye K, Yamano K, Maeno Y, Nakajima K, Matsuoka M, Wada Y, Sorimachi $M$ (1992) Iridovirus infection of cultured red sea bream, Pagrus major. Fish Pathol 27 : 19-27

Kasornchandra J, Khongpradit R (1997) Isolation and preliminary characterization of a pathogenic iridovirus agent in nursing grouper, Epinephelus malabaricus. In: Flegel TW, MacRae IH (eds) Diseases in Asian aquaculture III. FHS/AFS, Manila, p 61-66

Kurita J, Nakajima K, Hirono I, Aoki T (1998) Polymerase chain reaction (PCR) amplification of DNA of red sea bream iridovirus (RSIV). Fish Pathol 33:17-23

Langdon JS, Humphrey JD, Williams LM, Hyatt AD, Westbury HA (1986) First virus isolation from Australian fish: an iridovirus-like pathogen from redfin perch, Perca fluviatilis L. J Fish Dis 9:263-268

Matsuoka S, Inouye K, Nakajima K (1996) Cultured fish species affected by red sea bream iridoviral disease from 1991 to 1995. Fish Pathol 31:233-234

Nakajima K, Maeno Y (1998) Pathogenicity of red sea bream iridovirus and other fish iridoviruses to red sea bream. Fish Pathol 33:143-144

Nakajima K, Sorimachi M (1995) Production of monoclonal antibodies against red sea bream iridovirus. Fish Pathol 30:47-52

Nakajima K, Maeno Y, Fukudome M, Fukuda Y, Tanaka S, Matsuoka S, Sorimachi M (1995) Immunofluorescence test for the rapid diagnosis of red sea bream iridovirus infection using monoclonal antibody. Fish Pathol 30: 115-119

Nakajima K, Maeno Y, Kurita J, Inui Y (1997) Vaccination against red sea bream iridoviral disease in red sea bream. Fish Pathol 32:205-209

Nakajima K, Maeno Y, Yokoyama K, Kaji C, Manabe S (1998) Antigen analysis of red sea bream iridovirus and comparison with other fish iridoviruses. Fish Pathol 33:73-78

Oshima S, Hata J, Hirasawa N, Ohtaka T, Hirono I, Aoki T, Yamashita S (1998) Rapid diagnosis of red sea bream iridovirus infection using polymerase chain reaction. Dis Aquat Org 32:87-90

Submitted: July 16, 1998; Accepted: November 10, 1998

Proofs received from author(s): April 9, 1999 